Boise State University

ScholarWorks

6-1-2014

\title{
Private Lives and Interior Spaces: Raja Ravi Varma's Scholar Paintings
}

Niharika Dinkar

Boise State University 
This is an author-produced, peer-reviewed version of this article. The final, definitive version of this document can be found online at Art History, published by Wiley on behalf of the Association of Art Historians. Copyright restrictions may apply. doi: 10.1111/1467-8365.12085

\title{
Private Lives and Interior Spaces: Raja Ravi Varma's Scholar Paintings
}

\author{
Niharika Dinkar \\ Boise State University
}

Between 1900 and 1904, the celebrated Indian academic painter Raja Ravi Varma painted two depictions of men reading (plate 1 and plate 2). The works are unusual, so much so, as to be quite unrecognizable from the mythological paintings and princely portraits that earned Ravi Varma his reputation with patrons and clients. Ravi Varma was best known for his paintings of lovelorn women gazing comely at the viewer and although men had featured in several commissioned portraits they were rarely presented as idealised figures. His sketchbooks feature several examples of men in everyday scenes, so it is evident that he experimented with the idea but very few seem to have made the transition to a final painting. The two small paintings are not strictly portraits in the sense that there is no information on them being commissioned, nor do they present particular, distinctive individuals but rather represent characters within environments. They are, more properly, genre paintings that portray the subjects within scenes of contemporary life. At least two other paintings of men exist from the same period, The Retired Soldier (1902) and The Miser (1901) both of which are largely anthropological in nature. In the scholar paintings however, Ravi Varma attempts to go beyond the dominant paradigms of anthropological portraiture or studio portraits of the period in exploring the subjective potential of the Indian man in his private universe, a characterization that is explored with much empathy and sensitivity and throws light on the idealised male self in turn of the century Kerala.

The period between 1900-1904 was an eventful one for Ravi Varma that saw him assume the responsibility of his large joint family at Kilimanoor, lose his brother and close companion, C. Raja Raja Varma and receive the honour of a Kaiser-i-Hind medal by the Imperial government. It was also a period of hectic professional activity as he travelled across the country to fulfil commissions from various princely states, and participate in various exhibitions across the country. It is one of the best documented periods of Ravi Varma's career that saw the publication of his first biography Ravi Varma, the Indian Artist (1903) and we also have access to his day to day affairs from a diary maintained by his brother. ${ }^{1}$ In the midst of such momentous personal and professional change, how should we reconcile the paintings of men seated in leisurely repose within the interiors of a home warmly illuminated by lamps?

The subjects appear comfortably ensconced within these spaces, at home in the Westernized environment and engaged in a self-absorbed act of reading. As such, they offer an opportunity to glimpse inside the private spaces of an upper class home that would have otherwise remained unavailable to foreign eyes. In his discussion of domestic homes, Sir George Birdwood attested to the fact that such spaces generally remained out of bounds for the visitor: 'Europeans, as a rule, and all strangers are seen in the public rooms; and only intimate friends in the private apartments. ${ }^{2}$ Novels from the colonial period like Rabindranath Tagore's Ghare Baire (The Home and the World -1919) have described the differentiation of spaces within the Indian home where the interior chambers were reserved for domestic and family affairs while the outer spaces were made available for visiting guests and public affairs. Partha Chatterjee proposed that Indian nationalism emerged from a similar division of spaces where colonial mastery in the public realms of statecraft, science or the economy saw an emerging nationalism lay claim to the 'inner' spaces of the home and the family, which were invested with maintaining the sanctity of national culture. ${ }^{3}$ In recent years, Chatterjee's thesis regarding the strict separation of spaces between a westernized outside and an inner domain bearing the essential marks of cultural identity has been challenged as scholars have described a vibrant vernacular literary culture that negotiated colonial dominance in the public sphere. ${ }^{4}$ At the same time studies demonstrating colonial influence on homes or the public debates on domestic matters have suggested that interior spaces were equally transformed by the colonial encounter. ${ }^{5}$ In Kerala, J. Devika has argued that Partha Chatterjee's thesis did not quite apply, because the domestic domain was not preserved as a sacred 'inner space' outside the bounds of the modern state but was the site of major reform and transformation. ${ }^{6}$ In key legislation like the Malabar Marriage Act (1896), the reforms were sought by progressive Nayar men so the familiar binary of nationalist interests preserving 'tradition' and the colonial state's reformist agenda simply did not hold. Instead, various caste permutations between the Brahmins, the Nayars and the lower castes were far more influential factors in shaping public opinion. ${ }^{7}$ The simultaneous transformation of the agrarian economy with the creation of a new middle class that chose professions in bureaucracy and law saw domestic life transformed as large joint families were disbanded. 
This is an author-produced, peer-reviewed version of this article. The final, definitive version of this document can be found online at Art History, published by Wiley on behalf of the Association of Art Historians. Copyright restrictions may apply. doi: 10.1111/1467-8365.12085

With family life and property holdings transformed through a series of legislative acts the home too was imagined anew. Bourgeois identity increasingly defined itself in terms of the home, its collection of objets d'art, its craze for European furniture, plush curtains and rugs. While interior spaces had routinely been represented in pre-modern Rajput or Mughal painting, these interior chambers were usually situated within gardens or fortresses such that both the interior as well as its outer façade was presented to the viewer. ${ }^{8}$ Ravi Varma's visualisation of a cloistered interior space excludes any reference to the outside world except through the objects that find its way into the painting - westernised furniture, innovations like lamps that used kerosene to give a brilliant light and the reading material that functions as a window onto the world. ${ }^{9}$ As in his formal portraits, Ravi Varma's staging of objects is deliberate, evoking a tastefully decorated upper class home within which he situates his cosmopolitan reading subjects.

It is not accidental that the subjects portrayed are male. Two recent interventions have underlined how colonial modernity saw a re-alignment of gender relations within the unique feudal structure of the Kerala Nayar tharavad (household) where large extended families lived together and property passed along matrilineal inheritance laws. G. Arunima's work has focused on the political and legal reform that saw the dissolution of the matrilineal tharavad in colonial India. She argues that the interventions occurred at the behest of a younger generation of Nayar men whose desire for independent lives led them to break away from the tharavad and to insist on being allowed to inherit a share in the property. A series of legislative acts saw marriage norms transformed as men acquired the right to own private property. The social and legal bases for women's freedoms within the older kinship structures were effectively eroded. ${ }^{10}$ Meanwhile, J. Devika has argued that gender emerged as the fundamental indicator of difference in late nineteenth century Kerala as progressive reform in the public sphere envisioned a 'free' autonomous subject, reworking caste based identities of hierarchy and servitude. Although sexual difference had always structured social and domestic life in Kerala, the imagining of a modern individual identity saw new ideals of Manhood and Womanhood emerge, so that spaces of the public and the private were coded anew. Devika examines the fashioning of the 'Womanly space of the Domestic' as female education prepared women as capable overseers of the modern home, while manliness was linked to concrete forms of power and authority circulating in the public domain. ${ }^{11}$

In placing the man within the deepest interiors of the home, Ravi Varma seemingly goes against the grain of popular reform. However, as I will argue, this does not compromise his masculine authority, but in fact, extends it, by envisioning new spaces for men within the changing social and domestic landscape. In doing away with the central presence of women (and children) within the home, Ravi Varma imagines a private space inhabited by the solitary figure of the scholar, the only representations of an idealized male subject in all his work. As the large communal matrilineal multi-family tharavads based around agriculture in Kerala crumbled by the late nineteenth century, younger men increasingly travelled away from home to find careers in distant cities. Home acquired a new prominence in their imagination and nostalgic stories of travel and return in Malayalam literature redefined its place in the social psyche. ${ }^{12}$

The idealisation of the domestic interior as a space for repose and reflection belongs to a wider personalisation of interior spaces that accompanied modernity. As Walter Benjamin writes:

The nineteenth century, like no other century, was addicted to dwelling. It conceived the residence as a receptacle for the person and it encased him with all his appurtenances so deeply in the dwelling's interior that one might be reminded of the inside of a compass case, where the instrument with all its accessories lies embedded in deep, usually violet folds of velvet. ${ }^{13}$

Bourgeois notions of privacy, domesticity and comfort converged in the modern interior offering a place for selfreflection. The literature on European modernity has focused largely on the public reorganization of spaces of Haussman's Paris, the freedoms of the flaneur and the public anonymity of the streets as central to the modern experience. However, Haussmanisation was also accompanied by an inward turn, into private spaces that were reflected in nineteenth century European painting and architecture. ${ }^{14}$ As Penny Sparke points out, the interior was not just an abstract idea. It was consumed pictorially as a visual artefact, experienced spatially through architecture and materially through the furniture and objects d'art that filled its spaces. ${ }^{15}$ The interior was particularly suited to the solitary ideals of the scholar. 'To live in these interiors', wrote Benjamin 'was to have woven a dense fabric about oneself, to have secluded oneself within a spider's web, in whose toils world events hang loosely suspended like so many insect bodies sucked dry. From this cavern, one does not like to stir. ${ }^{16}$ If the public sphere formed an arena for the exhibition and contestation of identities, the domestic interior was no less crucial to the constitution of the modern self. 
This is an author-produced, peer-reviewed version of this article. The final, definitive version of this document can be found online at Art History, published by Wiley on behalf of the Association of Art Historians. Copyright restrictions may apply. doi: 10.1111/1467-8365.12085

\section{Darkness and Interiority}

The portraits of men reading are remarkable not only because they are the only two genre paintings featuring men in an oeuvre that compromises scores of female portraits, but also because it is one of the few times that Ravi Varma experiments specifically with chiaroscuro. While some earlier mythological paintings had also explored the use of light and shadow, the paintings of men reading were studies in indoor lighting and participated in the experimentation with lighting technologies that was making inroads in public culture in early twentieth century India. In her discussion of early German cinema, Frances Guerin has referred to a 'culture of light' within which developments in lighting technologies facilitated experiments with modern modes of representation. Ravi Varma similarly invokes a symbolic language of light and dark to relate the experience of modern life, and the gendered spaces within which the modern subject dwelt. ${ }^{17}$

Ravi Varma uses chiaroscuro not merely as an innovative tool to add to the pictorial realism of the scene but as a dramatic device that imbues the spatial relations of the figures with symbolic qualities. Chiaroscuro endows an everyday scene with a greater theatricality as the lights and darks dramatize the relaxed posture and slumped body even while retaining a pronounced intimacy that is absent in the formal portraits that Ravi Varma specialized in. The lights and darks are particularly suited to the portrayal of depth and interiority and despite the apparent disregard for the viewer, one might say both paintings are theatricalized presentations of the self.

Chiaroscuro was a newly learned device for Indian painters in the early twentieth century and its treatment of pictorial space appeared 'modern' to the Indian artists in that it presented illusionistic space. While the spatial implications of scientific perspective in shaping a worldview has been explored in contemporary visual studies, the more affective spatial relations encouraged by the use of chiaroscuro have received less attention. ${ }^{18}$ Ravi Varma uses light and dark to differentiate spaces, between foreground and background certainly, but he also uses the shadows and the illumination to produce social spaces concomitant with modernity. If the darkness is an encouragement to consider depth and reflection as marks of the modern individual, illumination is clearly associated with the act of reading. The singular importance accorded to education, particularly English education was in keeping with a recognition that it opened up possibilities for social mobility, for both lower caste individuals exploited by the caste hierarchy, as well as for the middle class, who sought careers in law and the administrative services. In the lower caste Malayalam novel Saraswativijayam (The Triumph of Knowledge) from 1892, Potheri Kunhambu tells the tale of an untouchable Pulaya who rose to become a judge presiding over a trial involving a Nambudri Brahmin who had many years earlier attempted to kill the Pulaya for the indignity of singing in his presence. 'Education is the greatest wealth of all,' declared Kunhambu in the epigraph, drawing upon the lessons preached by the Christian missionary reform movement in Kerala, which championed the cause of lower caste education. ${ }^{19}$ The middle class novel Indulekha (1889) likewise framed its entire plot around the importance of an English education for the younger members of the family, an initiative that was rebuffed by the older family guardians, with the conflict providing the basis for the tension between tradition and modernity in the novel. ${ }^{20}$ Both novels have been crucial for thinking about modernity and identity in Kerala and Ravi Varma was probably acquainted with them. ${ }^{21}$ Drawing upon a symbolic vocabulary of light, Ravi Varma immediately situates his subjects within the dialogues and debates in turn of the century Kerala.

The first work called The Student (plate 1) represents a bespectacled man sitting at a table in front of a lantern and immersed in a book. The lamp casts its glow upon the upper half of his body, on his face and his book, reflecting off the white garment he wears. He sits carelessly leaning his head against his hand, oblivious to everything but the book in front of him, a picture of what Michael Fried has referred to as 'absorption', in his analysis of modern painting. ${ }^{22}$ In the distant doorway, an indistinct figure of a servant is indicated, waiting in the shadows under a smaller lamp. Light here not only demarcates pictorial space between foreground and background but also indicates access to the world of education and reading. Unlike Ravi Varma's female subjects who are portrayed in lush landscapes or marbled courtyards, the world represented here is one of the solitary space of the scholar and his realm of books, with the man actively engaged in single minded intellectual pursuit and not cast in mindless reverie like his female models.

The second image Man Reading a Newspaper (plate 2) represents a young man reading a broadsheet within the interiors of an upper class home. The painting on the wall, the furnishings and the furniture all underline the westernized home of the subject. A seated figure in the foreground presumably holds a translucent fan in his left hand while a large ceiling punkah hovers above. Like the first painting, it is a remarkable experiment in the possibilities of using light and shadow within interior spaces, the large shadow of the reader's head on the wall forming a dramatic diagonal between 
This is an author-produced, peer-reviewed version of this article. The final, definitive version of this document can be found online at Art History, published by Wiley on behalf of the Association of Art Historians. Copyright restrictions may apply. doi: 10.1111/1467-8365.12085

the three heads. The absorbed subjects in both paintings deny the presence of the beholder announcing an affinity with westernised painting, which directly repudiates the frontality of popular devotional imagery that relies upon the visual transaction of darshan between the devotee and the deity. ${ }^{23}$

In both paintings the play between light and dark produces spaces. This is to say, following Henri Lefebvre, that the light does not merely reflect an already existing space, but produces it socially - as a product of perceived, conceived and lived spaces. ${ }^{24}$ Chiaroscuro is particularly compelling in its rendition of indoor space and Ravi Varma exploits this aspect to create interior spaces, subjective 'inner worlds' set within private rooms in westernized homes. The notion of the self in nineteenth century Kerala has been the subject of much literary and historical analysis and in its evocation of depth and interiority, Ravi Varma's paintings participated in the fashioning of a modern identity in Kerala that was simultaneously expressed in the Malayalam novel. ${ }^{25}$ Sudipta Kaviraj has argued that the idea of 'private life' is a historical construction of western modernity and although some notions of privacy existed in pre-modern Indian life (personal religious reflection, for example), the idea of an interiority linked with individual identity was particularly new in the Indian context in the late nineteenth century. Given voice in the realist novel or autobiographies, it mediated earlier forms of self- expression to forge new relationships between the individual and his world that approximated to what Kaviraj calls 'the invention of private life. ${ }^{26}$ These two portraits are examples of such an invention of a 'private life', figured upon the self-absorbed reading subjects and situated in a personal, intimate space produced by lights and shadows. After all, private life was 'invented' not only through personalized acts of reading and writing and given voice within the literary sphere but found a place within the home, burrowed deep within its interior.

The deep shadows and luminous whites articulate a tension between a public visibility and a private interiority that is echoed by the subject nestled deep within the interiors of a comfortable home while also engaging with the public world of letters. At first glance the paintings could well serve as posters for Benedict Anderson's influential thesis on national identity as an 'imagined community' fostered through the products of print capitalism. ${ }^{27}$ And indeed, the mass circulation of Ravi Varma's mythological prints have been seen as providing a visual template in the imagining of a national identity by readers like Partha Mitter. ${ }^{28}$ In these portraits of the cosmopolitan man who transcends regional affiliation, Ravi Varma appeals to the elite Indian subject that historians have identified as singularly important in the crafting of a national identity. A product of European education and tastes, he stood at the intersection of the colonial government and local communities. It was this newly visible middle class that was responsible for creating the dominant forms of nationalist culture, modernising the vernacular discourse within the terms of European institutional structures.

In an undated painting of Ravi Varma by his brother C. Raja Raja Varma titled Ravi Varma in Mourning (plate 3), he is shown in a similar pose to the readers, bent over a book with a flowing beard as the glow of a hidden lamp illuminates his face and upper body. Rupika Chawla has disputed the claims that the figure is indeed Ravi Varma mourning the death of his uncle in 1883, noting the discrepancy between Ravi Varma's age at that point (thirty five) and the older greying subject portrayed. ${ }^{29}$ However, Ravi Varma spent a year in mourning in 1896 when his maternal uncle Raja Raja Varma died and possibly also mourned the death of his cousin Kochu Koil Thampuran who died in 1903 after which he became head of the family. ${ }^{30}$ Raja Raja Varma could well be referencing any one of these events, or even recalling the mourning scene at a later date, but the 1903 date would place the painting in conjunction with Ravi Varma's own experiments with light and shadow. If we do accept that it is indeed Ravi Varma depicted here, then the two scholar portraits assume an autobiographical dimension that would not only suggest that the scholar paintings were based upon a personal experience of the intimate pleasures of reading but also attest to a desire for privacy afforded within the domain of the bustling tharavad, taking refuge in the prescribed rituals for mourning. ${ }^{31}$

These paintings of men reading are not the only examples of reading subjects from the colonial period. An undated painting by the contemporary Parsee artist Pestonjee Bomanjee (1851-1938) also depicted a young man seated upon a chair facing the viewer and reading a newspaper (plate 4). Bomanjee's instruction at the J.J. School of Art in Bombay had trained him in the academic realism that was popular amongst the students and faculty at the art school and his painting bears the marks of that orientation. Like Ravi Varma's paintings, it has very few props and is similarly lighted, with the glow upon the man's face even though the source of light is not made evident in the painting. The canvas upon the easel towards the corner of the painting bears a landscape, pointing to the profession of the subject as an educated, cultured artist. The Goan painter Antonio Xavier Trindade (1870-1935) who was also trained at the J.J. School of Art, similarly excelled in intimate portrayals of the interiors of the home. One painting depicting children crowding around a table studying in the light of a lamp makes use of a dramatic light and shadow that suggests a common vocabulary for representing reading. It is quite possible that Ravi Varma borrowed after the Bombay artists - he had certainly seen 
This is an author-produced, peer-reviewed version of this article. The final, definitive version of this document can be found online at Art History, published by Wiley on behalf of the Association of Art Historians. Copyright restrictions may apply. doi: 10.1111/1467-8365.12085

their work at exhibitions and even at their studios, however I have been unable to ascertain any evidence of a direct correspondence between them. While space prohibits me from undertaking a closer examination of the Bombay artists and their specific investment in reading and education, what is pertinent here is the common focus on reading as a sign of a cultured mind and its promises of social mobility.

Ravi Varma's focus on the pleasures of the book and the private act of reading pointed to the explosion in print cultures that accompanied modernity in nineteenth-century India. The boom in commercial publishing resulted in a wide variety of texts that not only drew from elite literary and poetic sources but also included mass-produced entertainment literature and the scribal culture associated with the 'document raj' of governmental bureaucracy. ${ }^{32}$ These texts intervened in a pre-print world of oral performance and manuscript culture producing new literary habits but did not entirely replace them. A photograph of Ravi Varma seated in his studio in Kilimanoor portrays the traditional mode of learning - the recitation of texts from a Brahmin priest (plate 5). ${ }^{33}$ In his dhoti and with an uncovered chest he sits on the floor in the company of two men, one of whom reads out aloud (from a book) to him. Another sketch entitled 'Reading the Palm Leaves' in his diaries includes a dhoti-clad man seated on the ground holding out his left hand with a palm leaf manuscript (<Collection>, < <ocation $>$ ). That Ravi Varma was intimately acquainted with a pre-modern performative tradition and yet chose to focus on books points to his own predilections for a world where books suggested a cultivated mind that was associated with an elite class. This is underlined in his portraits where they frequently serve as props - his portrait of Kerala Verma includes a leather bound volume of 'Byron's Poetical Works' ( $<$ Collection>, $<$ Location $>$ ), or his portrait of Maharani Lakshmibai includes books with titles like 'Near Home or Europe Described' and 'The Young Lady's Book' (<Collection>, <Location>).

Despite the sparse interior spaces where books serve as the primary props, the dramatic lights and darks situate the portraits of men reading within homes that provide places for privacy and reflection. What did interior spaces look like in nineteenth century Kerala and if, as Sudipta Kaviraj argues, private life was 'invented', what spaces did it inhabit? My analysis examines how private space figured in domestic architecture and family life, its implications for gender and social relations and finally how a new idea of home emerged in tandem with a territorial imagination fuelled by the new possibilities of travel in late nineteenth century Kerala.

\section{Interior Spaces}

The most striking visual images of interior spaces from nineteenth century India are undoubtedly Deen Dayal's photographs of the opulent palaces that he was invited to document (plate 6). Crammed with crystal chandeliers, marble statuary, imported furniture and carpets, they portray the manner in which Indian royalty was adopting European tastes in decorating interior spaces. Ravi Varma was a frequent guest at the palaces of the rulers of Mysore, Baroda and the Nizam of Hyderabad, all of whom spent extravagantly in furnishing their many homes and public buildings. In fact, Ravi Varma's commissions of royal portraits and mythological paintings (at Mysore and Baroda) formed part of the budget for decorating these palaces. However, it was not just royalty that adopted these trends but elite collectors like Raja Rajendra Mallick whose Marble Palace in Calcutta was stocked with academic art, carpets and marble statuary, or the merchant R. K. Jalan, whose collection included Chinese ceramic ware and French tapestry and furniture in his Quila House in Patna. ${ }^{34}$ Lord Curzon, the British Viceroy denounced the craze fuelled by 'globe trotters and curio hunters' that had a negative impact on Indian art and handicrafts. 'So long as they prefer to fill their palaces with flaming Brussels carpets, with Tottenham Court Road furniture, with cheap Italian mosaics, with French oleographs, with Austrian lustres, and with German tissues and cheap brocades, I fear there is not much hope,' he declared. ${ }^{35}$

The enthusiasm for Western academic art and interior furnishings was also expressed in the contemporary Malayalam novel. In her study of the early novel, G. Arunima has discussed the transformation of the home as an exhibition space for such 'baubles of modernity', and points out that many early Malayalam novels (Indulekha, Meenakshi, Lakshmikeshavam) set themselves within bourgeois Victorianized homes. ${ }^{36}$ In fact, a distinction is marked between valuable objects of an earlier world - golden shawls, boxes of gold and silver, golden watches and the more 'English objects' that the heroine Indulekha prefers. ${ }^{37}$ In a description of the stately mansion in Calcutta, the author goes into raptures describing the beautiful crystal chandeliers, the velvet beds, gilt statues and fountains that graced the mansion so much so that he was transported into a 'land of fantasy'. ${ }^{38}$

While Ravi Varma's mythological paintings were frequently staged within these sumptuous spaces with marble columns and silk curtains that seek to bridge the gap between the ancient India he recalled and contemporary tastes, the two paintings of men reading are set within more austere settings with minimal props that are nevertheless distinct 
This is an author-produced, peer-reviewed version of this article. The final, definitive version of this document can be found online at Art History, published by Wiley on behalf of the Association of Art Historians. Copyright restrictions may apply. doi: 10.1111/1467-8365.12085

and personalized. The painting of the scholar indicates him seated upon a chair and a reading desk and in the second work the room contains several pieces of furniture - at least two upholstered chairs, a writing desk and an upholstered settee upon which the reader sits. The westernized furniture is striking if only by its very presence. If elite homes were crammed with objets d'art, British accounts of the period note with astonishment the utter lack of furniture in middle and lower class Indian homes. ${ }^{39}$ In this, Nayar homes were no different from their north Indian counterparts. A census report of Travancore from 1871 describes the furniture in Nayar homes as "scanty", comprising a cot and a few mats besides bronze lamps and pitchers. ${ }^{40}$ Of the spacious tharavad in Marthanda Varma, Pillai writes "Although the family was amongst the richest of the land, most of the rooms in the house were not furnished in a style suitable for healthy occupation. ${ }^{41}$ Ravi Varma's subjects occupy a middle ground between an obsessive craze for English goods and an 'artful' fashioning of the interior that was nevertheless furnished entirely with Westernized objects.

The intimacy and familiarity of the subject within the space he is situated in are a marked departure from the many staged mythological scenes or studio portraits that abound in Ravi Varma's oeuvre. The stiff postures and awkward figure-ground relationships that were the result of painting the backdrops separately from the figures in the majority of his works have inspired ironic contemporary citations precisely for their clumsy integration of the figure into the background space. ${ }^{42}$ In these paintings however, the subjects appear comfortably ensconced within the spaces like the deep folds of the compass case that Walter Benjamin had pointed to. The staged quality of the painting is effectively disguised and the home with its modern baubles is presented as natural. However, there is little evidence to suggest such spaces were at all commonplace. They are products of Ravi Varma’s visual imagination.

In both paintings, we are given a very limited view of the home, but even within that restricted space, Ravi Varma evokes a notion of personal space where the individual is able to pursue his reading undisturbed. Such a demarcation of private spaces for individuals within homes was a relatively uncommon phenomenon in India, according to the architecture historian V.S. Pramar. By and large Indian homes were not designed for privacy and an easy communion between the spaces outside the dwelling and the rooms within, meant that exclusive spaces like those visualized by Ravi Varma were not common. The interior spaces are moreover polyvalent in Pramar's description, with spaces and objects shared amongst joint family members with little differentiation between the functions for each room. '....since no part belonged to anyone, it never had a personal quality, it contained no pictures or décor selected and put in place according to any one person's taste, in short, the household and all it contained was relatively 'impersonal', including its architecture. ${ }^{43}$

Pramar's observations are based on the joint family dwelling in western India and these would be modified somewhat in Ravi Varma's native Travancore. In the typical Nayar home, the matrilineal joint family structure was based within the large compound of a tharavad, the term serving to describe both the kinship structure as well as the particular architecture that housed these families. Wealthy Nayar homes were constructed around a number of open courtyards (nalukettu) that let in light and employed beautifully carved wooden panelling to screen out the sun. Large tharavads comprised several smaller separate buildings and suites secluded for the use of individual households comprising a married woman with her children (tavazhis) and this allowed for a fluid movement between the more public spaces of the larger family and somewhat more private spaces. ${ }^{44}$

All men, except for the head of the household (karanavan) who lived with his family, were relegated to common bachelor rooms or dormitories, which provided for little space other than for sleeping. Unlike the women's spaces, which formed the heart of the household, the men's chambers were minimally connected, being accessible only from the common public spaces. In newer constructions, men's spaces were limited to the front courtyards and living spaces directly behind them while the interior bedrooms, storage rooms and religious spaces were reserved for women. ${ }^{45}$

At Kilimanoor (Ravi Varma's ancestral home) there were separate apartments for women and even common spaces such as the performance arena where Kathakali dances were held had separate chambers for women. Despite the gendered segregation of spaces, it is important to note that even these chambers were not personalised, and allowed access to different publics, including household servants (of the authorized caste), family members and children. At both Kilimanoor and Mavelikkara (his wife's tharavad) Ravi Varma had his own studio space that might have provided him a solitary haven from the daily bustle of the tharavad. Regardless of his personal situation, which also included temporary homes (and studios) in Bombay and Madras amongst other Indian cities, the paintings position a tension between the communal character of the household, the lack of access for men within interior spaces that was undoubtedly the prevailing norm and the deeply personal act of reading within the comforts of the home. 
This is an author-produced, peer-reviewed version of this article. The final, definitive version of this document can be found online at Art History, published by Wiley on behalf of the Association of Art Historians. Copyright restrictions may apply. doi: 10.1111/1467-8365.12085

Contemporary Malayalam novels affirmed the tharavad as a hub of activity bustling with servants, extended family members and guests. In the historical novel Marthanda Varma (1891), the author C.V. Raman Pillai situates much of the action within the spaces of a sprawling Nayar tharavad described as spacious and well ventilated with courtyards including separate chambers for women, guest rooms, an armoury for weapons, a temple for the household gods, as well as secret cellars and tunnels. ${ }^{46}$ The contemporary Malayalam novels however, indicate a predilection for private spaces and in Indulekha, we are made aware of her apartments, its tasteful décor and her suitors’ ritualised access to it. This new idealisation of personalised spaces within the home is repeated in the paintings.

A reading of the paintings as evocative of domestic life in Malabar is not borne out by the architectural evidence and there is no suggestion that Ravi Varma is indeed referring to his own home in these paintings, since it depicts a space that is not in any way identifiable with the typical tharavad. His own studio in Killimanoor was in fact, brightly lit with natural light flooding in and Raja Varma's diaries note how the brothers specifically installed windows in their Bombay studio to assist with their painting. ${ }^{47}$ Here, no outside light enters the darkened chamber of the room illuminated artificially by the glow of a lamp. The westernised home may in fact, be seen as an interior counterpart to the transformations in public architecture in the late nineteenth century, where neo-classical and neo-Gothic styles were incorporated in architectural projects sanctioned by the ruler Ayilyam Thirunal (who had also extended his patronage to Ravi Varma) ${ }^{48}$ Yet, C. Raja Raja Varma writes of the features that determine a Malayali home, ${ }^{49}$ 'the paintings, the huge elephant's tusks, the ivory knick knacks, nay the very beams and door posts of massive teak', and it is clear that Ravi Varma makes no effort to include any of these in the paintings. ${ }^{50}$

In female portraits, dress and jewellery were used to signify caste and ethnic identity, but here the deliberate representation of an ambiguous space to represent the men spoke to the experience of Nayar men like him who had travelled the breadth of the country and had access to the more cosmopolitan, urbane spaces afforded in the cities. Instead the attempt is to present a modern Westernized ideal that transcends regional identity for a more cosmopolitan one. ${ }^{51}$ The moustache the subjects sport were quite unfashionable in the day amongst Malayalis and the simple cap that covers the head was likewise not an aspect of the dress of Malayali men. ${ }^{52}$ Noting the peculiarity of Malayali men in not wearing caps, Raja Raja Varma points to its common presence in Bombay in his travel writings, where to be seen without one would be amiss and cause the person to be taken for a mourner or a convict. ${ }^{53}$ The basic caps worn by the figures are perhaps more of the order of the 'made up head-dresses' that J. Forbes Watson (1827-1892) had described in his exhaustive catalogue of ethnographic attire. In Watson's definition these were 'articles of attire ... more in accordance with our European notions of clothing. ${ }^{54}$ Unlike the traditional turbans that had characterized ethnic identity (and Watson catalogues several different examples with a view to assist the trade in textiles), these were simple skull-caps, sometimes embellished with embroidery or golden thread.

The simple attire indicates an easy adoption of western articles of clothing like shirts along with the achkan and mundu and points to the changing sartorial tastes of Indian men as they adapted items like shirts to suit their own stylistic preferences. ${ }^{55}$ The choice is a marked departure from the clothing catalogued in ethnographic studies like that of Francois Balthazar Solvyns (A Collection of Two Hundred and Fifty Coloured Etchings: Descriptive of the Manners, Customs and Dresses of the Hindoos, 1799) or J. Forbes Watson's Peoples of India (1868-1875). In these projects they had catalogued 'native clothing' to serve as a marker of ethnic identity and Ravi Varma himself had experimented with the idea most notably in his Galaxy of Musicians (1889) where women from the different regional provinces of India were clad in regional dress in a conglomerate that pointed to a nascent idea of the nation. By the late nineteenth century, Indian adoption of western clothing was actively mocked in broadsheets like the Indian Charivari or in Kalighat satires about the westernized baboo figure. ${ }^{56}$ In fact, Ananda Coomaraswamy's first publication upon his return to India from England in 1902 was a tract called "Borrowed Plumes" that critiqued the Indian adoption of westernized clothing.

The decision to represent the men in a mix of westernised clothing is therefore a deliberate one that underlines the hybrid identity that Ravi Varma presents as an ideal here. The elite - wealthy Parsis in Bombay and minor royalty had started mixing Indian and European garments by the late nineteenth century and Ravi Varma's naturalisation of such mixed dress probably relied upon their experiments. ${ }^{57} \mathrm{It}$ is a departure from the ethnic boundaries within which female identity was cast, where clothing signified regional affiliation. The male subject personifies an ideal that is representative of the newly emerging class of educated professionals, rather than identified by ethnic markers. In using the male body to signify the hybridised ideal, Ravi Varma participates in a re-fashioning of the visible indexes of the modern self that so engaged his contemporaries. 
This is an author-produced, peer-reviewed version of this article. The final, definitive version of this document can be found online at Art History, published by Wiley on behalf of the Association of Art Historians. Copyright restrictions may apply. doi: 10.1111/1467-8365.12085

\section{Phallic Solitude}

The very representation of the man within the deepest interiors of the home must be viewed in light of prevailing domestic relations within Kerala in the early twentieth century when a well-established matrilineal system came under attack by younger Nayar men choosing independent lives. The Nayar tharavad was traditionally a space centred around the women of the house (although the head of the household was the maternal uncle, the karanavan), and one explanation for the very emergence of the matrilineal structure was the relative absence of Nayar men who were recruited as militia in armies far away from their tharavads. ${ }^{58}$ The women of the tharavad had informal hypergamous marriages with members of the Nambudri Brahmin community who did not reside with them and the children borne of the alliance remained part of their mother's tharavad as property passed along the mother's lineage. While some Nayar men remained within the tharavad and attended to the land holdings and properties held in joint custody, the most highly regarded marital alliances of Nayar women were with the Nambudri Brahmin men. ${ }^{59}$

By the late nineteenth century, the place of the Nayar man within this structure had become increasingly ambiguous. His role in the military had diminished under the colonial system and more and more younger members of the tharavad found jobs in the legal system or the colonial administration, reducing their dependence on the tharavad.

In the 1880s, a growing disaffection with the family structure of the tharavad had manifested itself, led by younger Nayar men who resented the Nambudri interference in the tharavad. Voiced in newspapers and magazines and also in contemporary Malayalam literature, it pointed to an embarrassment with the 'promiscuous polyandry' of the Nayar women, a view that British anthropological accounts had popularized. ${ }^{60}$ The call for a transformation in the matrilineal structure sought legal reform to garner property rights for men through the Malabar Marriage Act, which was eventually passed in1896. It proposed a nuclear family model that allowed for monogamous conjugal relations with Nayar men and also responded to the needs of modern Nayar men making independent careers for themselves outside the feudal structure of the tharavad. Ravi Varma's There comes Papa, 1893 (plate 7) intervenes in this debate with its presentation of a young mother with her child standing within the confines of a westernized home. ${ }^{61}$ With the dog on her right, it is clearly a bourgeois offshoot of contemporary Victorian images of the expectant mother waiting for the father to complete the picture of the small, happy nuclear family. The central figure in the painting was Ravi Varma's own daughter, someone whose own life was spent within the traditional tharavad, yet she is represented here as an icon for the new family ideal. ${ }^{62}$

R. Nandakumar's reading of There Come Papa has recalled the absence of male figures in Ravi Varma's paintings, reasoning that it pertains precisely to the absence of a social space for their representation within domestic and family life. Since fathers were never part of the household but merely visited their wives and children, there was never any emotional investment of the father with his family. Socially acceptable codes of behaviour between men and their wives and children were distant and formal, based upon rules of decorum dictated by social status and rank. A photograph described as 'Ravi Varma at home with his wife and eldest daughter' in N. Balakrishnan Nair's biography consists of two separate photographs, one of the mother and daughter, and the other one of him in exactly the same chair at the same spot. Drawing from this representation of family life, Nandakumar proposes that the numerous Ravi Varma paintings of women yearning for their lovers represented a new emotionality invested in marital relationships, missing from the previous generations, and made possible by the calls for a nuclear family.

Nandakumar notes with amazement the utter absence of male figures in Ravi Varma's works where even the karanavan (the maternal uncle who served as the head of the tharavad) is never represented despite his frequent portrayal in contemporary Malayalam literature as a despotic figure. This absence is all the more significant because amongst Ravi Varma's earliest paintings was that of the grand matriarch (Amma Thampuran) and several portraits of the female members of the tharavad exist. Nandakumar concludes that in Ravi Varma's experience there were no prototypes of men that could serve as an ideal self-image, as he could not identify with either the traditional Malayali man nor the common dhoti-clad image of his fellow countrymen that he rejected from his view of sophisticated urbanity. 'There was no male image forthcoming that could privilege itself by being identified with that which was ideologically masculine as constituting the artistic self-image. ${ }^{63}$ It is unclear why Nandakumar does not consider the pair of images of men reading as serving exactly that 'artistic self-image', but it is quite possible to see the overwhelming impact of Ravi Varma's female figures as occluding the very existence of the few male genre paintings. 
This is an author-produced, peer-reviewed version of this article. The final, definitive version of this document can be found online at Art History, published by Wiley on behalf of the Association of Art Historians. Copyright restrictions may apply. doi: 10.1111/1467-8365.12085

In fact, showing the men ensconced within the very interiors of the home is an attempt to situate the male figure within the domestic space, displacing the primacy of the female figure in the Malayali imagination, while also dismissing the common Victorian association of the woman with the home and the hearth that he had portrayed in There Comes Papa. And yet, the interior spaces represented in both paintings are not so much domestic spaces with the appurtenances of family life and children, but quiet, secret places inhabited by what Gaston Bachelard has referred in his analysis of intimate spaces, as 'psychic weight' ${ }^{64}$ Bachelard describes the home as an imagined space, as much a product of memories and daydreams, as it is of the walls, corridors and cellars that define it. The home 'is the human being's first world' whose maternal, protective spaces are kept alive in the imagination, even when they might cease to exist in the real world. Ravi Varma here re-imagines the home, not as a domestic space with the woman at its centre but an interior space for the performance of a private life.

The absence of women from this space would tend to underline Nandakumar's thesis regarding the separation of spaces of men and women in Ravi Varma's family history. However, it also brings to mind, the notion of 'phallic solitude' that Henri Lefebvre attributes to modern spaces in the early twentieth century. ${ }^{65}$ Lefebvre's description of abstract modernist space associates an aggressive masculinity with the phallic verticality, the authoritarian town planning and the repressive spaces of modern bureaucratic machinery, but such a description of phallic solitude could just as well apply to the cloistered space within which the male subject is depicted here. In his discussion of the homosocial spaces of the adda in nineteenth century Calcutta, Dipesh Chakraborty also invokes Lefebvre to draw attention to the exclusively male literary culture that accompanied modernity in the city.$^{66}$ The adda was an informal social gathering held in coffee shops and book-stores or in the outer parlours of homes of its members, where according to Chakraborty, a democratic speech that characterized the spaces of urban modernity, flourished. He attributes the exclusion of women from the adda to the gendered separation of spaces in the traditional Bengali household where the adda was necessarily seen as opposed to interior domestic spaces ${ }^{67}$ Chakraborty's discussion of adda has emphasized its oral culture as well as its convivial communitarian character but what of the private solitary spaces of reading and writing that were equally aspects of the literary cosmopolitanism Chakraborty celebrates? A pen and ink sketch of the famous literary and artistic adda that gathered around the Calcutta home of the Tagores by the artist Nandalal Bose (plate 8) provides a glimpse into the co-existence of private acts of reading and the shared space of learning in a homosocial environment. The three Tagores feature in the background, lounging on chairs and reading while Ananda Coomaraswamy makes a point to Nandalal Bose as he crouches in front of him. Intellectual spaces were undoubtedly coded as masculine, even when they were part of the home, as exemplified in the Bose sketch.

The insertion of the male subject within the interiors of the home was not simply a transgression of the gendered separation of spaces but a displacement of the matrilineal structure with a newly instituted patriarchal order. Between 1887-1896 the matrilineal household was the site of a protracted battle between the older members of the tharavad with their hierarchical caste values and its younger members who sought individual freedoms, away from the strictures that bound the large joint family. ${ }^{68}$ The redefinition of family life that they sought was solemnized with the passage of the Malabar Marriage Act in 1896, which granted Nayar men both property and conjugal rights and is regarded as a signal event in the narrative of Nayar personal identity. In view of this bitter conflict within the home, Ravi Varma's romanticized presentation of the home in these paintings takes on an added significance. In Man Reading a Newspaper rather than depicting the disaffection between the generations that characterized life in the tharavad, Ravi Varma instead presents a harmonious portrait with the older man seated to the left watching over the younger man reading. In his left hand, he presumably wields a handheld punkah that sits in the centre of the painting, performing a task that would typically have been assigned to the lowliest of servants.

Ravi Varma does not portray the older man in the guise of the much-reviled figure of the karanavan (the maternal uncle who was the head of the tharavad) who was known to trivialise the benefits of an English education and forbade the younger members (ananthavaran) from wasting money on it. In Indulekha, the karanavan is portrayed as a crotchety old figure with a vile temper whose dictates were resented by the members of the tharavad and who stood as an order of the old guard refusing to be swayed by the promises of modernity. ${ }^{69}$ In the painting on the other hand, the older man in his elegant long jacket and mundu mark him as a more modern figure and unlike the karanavan's disregard for the younger men's English education, the paternal figure here takes an active interest in the younger boy's education, doting upon his kin with the most menial of tasks. He literally takes the back seat here while allowing the boy to be cast out into the light, and the implied indulgent relationship is a criticism of the domineering ways of the karanavan who was seen as controlling the lives of the younger men of the tharavad, not supporting their educational 
This is an author-produced, peer-reviewed version of this article. The final, definitive version of this document can be found online at Art History, published by Wiley on behalf of the Association of Art Historians. Copyright restrictions may apply. doi: 10.1111/1467-8365.12085

pursuits or their desires to travel away from the tharavad. In its portrayal of an idealized resolution of a protracted problem within the home, the painting endorses the narrative of individual freedom centred around the progressive male members of the household within which the transformation of the tharavad was cast.

The large shadow that falls upon the back wall of the painting is undoubtedly that of the young boy reading however, given that the source of light is obscured, the shadow casts an ambiguity that is disconcerting, in that it repeats the shape of the older man's head. It is tempting to read the shadow as the disembodied presence of the dreaded figure of the karanavan, the 'head' of the disintegrated tharavad who exists as the ghost of a past that casts its shadow upon the present. What is more likely however, in this representation of the elder figure watching over the younger man is Ravi Varma's own complex position as he assumed the place of the karanavan in his tharavad in Kilimanoor. In 1903, following the death of his cousin Kochu Koil Thampuran, Ravi Varma took over the responsibilities of the large tharavad which consisted of more than a hundred members. In his biography, Veniyoor noted Ravi Varma's unhappiness about the assumption of such responsibilities that took away from his painting and traveling but reported that he eventually submitted to the call of duty. ${ }^{70}$ The figure seated in the foreground could well be a self-portrait for the moustache and facial features resemble those of Ravi Varma's official portrait when he received the Kaiser-i-Hind medal, although what is presented here is a younger version of himself.

The easy comfort between the two men speaks of Ravi Varma's need to distance himself from the stereotype of the repressive karanavan while the dark silhouette hovering on the wall is an uncanny reminder of his uneasiness in his new role. On the other hand, the large ambiguous shadow unites the common aspirations of the two men who privilege the values of education and the written word in a meeting of minds underlined by their common headgear. Together, the three heads create a dramatic diagonal that draws them into a silent patrilineal alliance that does away with the fraught relationship between the karanavan and the ananthavaran as a thing of the past and presents an idealized vision for the future. What is striking in this presentation of the past, present and future each notably figured as a man's head, is the absence of women, given their prominent role as powerful matriarchs within the older system. One could, in turn, point to the case of the 'missing female' to rephrase Nandakumar's intriguing question and once again, I propose that the rejoinder of a gendered separation of spaces does not quite answer to her absence.

In Indulekha, the heroine is presented as an educated woman fond of reading and capable of holding her own amidst her suitors, but she refrains from presenting political views, restricting her wit and learning to literary subjects and musical accomplishments. A particularly long chapter near the end of the novel is a conversation that takes place in Bombay between Madhavan, her young lover who has left the tharavad because of a tragic misunderstanding, his father Govindapanikkar and another distinguished family elder, Govindankuttymenon. The three have a serious discussion about everything from Darwin's theory of evolution and the existence of God to national politics and religion and it is clear those are subjects reserved for discussion between men. This view regarding appropriate topics for men and women was echoed in the public sphere, which saw the birth of the genre of the woman's magazine in Kerala. The Keraleeya Sugunabodhini declared at the very onset in 1892, 'We will publish nothing related to politics. Principles, physiology, entertaining tales, writings that energise the moral conscience, stories, Womanly Duty, the science of cookery, music, biographies of ideal women, the history of nations, book-reviews and other such enlightening topics will be published... ${ }^{71}$ In a painting that has been attributed to Ravi Varma (but is of uncertain provenance) and is undoubtedly modelled on the character of the heroine Indulekha, a reclining Nayar woman sits poised upon a velvet couch with a book open in front of her. Like her male counterpart she has a dark skinned maid attend to her, however unlike the male portraits of the self-absorbed reader, she comely accepts the gaze of the viewer typifying what Hollis Clayson has referred to as 'absorption light' in her analysis of prints of women reading in nineteenth century France. ${ }^{72}$

In fact in Man Reading a Newspaper, the only prominent decorative motif in the room is a framed painting of a woman, of the kind Ravi Varma himself excelled in portraying - the sensual mythological heroine. The figure is deliberately indistinct, but the posture relates it to his most celebrated painting of Shakuntala reclining on the grass in the woods and writing a letter to Dushyanta, her lover, on a lotus leaf. Shakuntala Patralekhan had won accolades at the Madras Fine Art Exhibition in 1876 and had been acquired by the Duke of Buckingham and also used as the frontispiece for Monier Monier-Williams' translation of the Sanskrit classic by Kalidasa. Endorsed thus by the cultural elite, this citation of his own work presents the woman as trophy, to be framed, collected and displayed on the walls of the modern home in a gesture that speaks to his entire body of work. 
This is an author-produced, peer-reviewed version of this article. The final, definitive version of this document can be found online at Art History, published by Wiley on behalf of the Association of Art Historians. Copyright restrictions may apply. doi: 10.1111/1467-8365.12085

\section{The Home and the World}

The re-imagination of the home as an idyllic retreat for the self was at once a response to the dissatisfaction within the tharavad, but in its choice of the reading subject, it presented a path to escape the confines of the household. The dissolution of the tharavad that saw its younger members seek a career outside it was largely dependent upon the social mobility afforded by an English education. The reading subjects are emblematic of the new identities fostered under an English education, men whose tastes are cosmopolitan and who have ventured outside the home and travelled as part of their education only to return to the sanctuary. The paintings showing the subjects comfortably cocooned are all the more remarkable because they were painted during a period (1900-1904) when the Varma brothers were traveling across India for professional reasons, fulfilling commissions, attending to their printing press near Bombay or overseeing their properties within Kerala. The peripatetic brothers were rarely in one city for longer than a few days, sometimes even a few hours, as they criss-crossed the breadth of the nation by trains, carriages, or boat. Ravi Varma's sketch-book includes random vignettes from his travels, including scenes of a train, a woman directing a porter with her luggage, and street scenes. Raja Raja Varma diligently kept a diary, which documented his travels and even composed a narrative of his journey to North India when he and his brother accompanied the Prince of Travancore, Marthanda Varma in 1896. Prior to this in 1888-89 they had also undertaken a long tour of north India with the express purpose of studying ancient costumes to prepare for a large commission of mythological paintings for the Gaekwad of Baroda. ${ }^{73}$ Ravi Varma's investment in the interior makes sense only in light of his peripatetic lifestyle and his travels across the nation. Just as the geographical spaces of the nation were invested with desires and fantasies in paintings like The Galaxy of Musicians, the home too was imagined anew as a comfortable familiar space for the staging of an interior life. The presentation of the secluded interior as a space for repose was a common trope in nineteenth century European imagery and it has often been interpreted as an anchor for the rootless and alienated subject of modernity. ${ }^{74}$ Charles Rice argues however that the emergence of the interior as a cultural form in the nineteenth century was not simply an answer to the problem of the homelessness of modernity but in fact one of its mechanisms, enacting modern norms of domesticity. ${ }^{75}$ The modern interior then was a paradoxical space that at once conveyed the desires for stability in a world conditioned by the impossibility of retreat and immersion. Certainly, the bourgeois interior was a familiar subject of much Victorian imagery and Ravi Varma was undoubtedly acquainted with the trope from his subscription to various European artistic periodicals, but it was also a response to the modern experience of anonymous public space. ${ }^{76}$ Throughout his travels across India, Ravi Varma encountered transitional public spaces - dharamshalas, guesthouses, dak bungalows, chattrams, he even rented a temporary house in Bombay. The home in the paintings is instead invested with a comfort and familiarity that bears the marks of individual presence almost as a denial of the impersonal spaces that were a part of his life and travels.

C. Raja Raja Varma's diaries underline the importance of travel, both as a means for professional success as well as a kind of cultural education. Carefully noting Ravi Varma's first trip away from home (a pilgrimage tour of the Mukambika temple on the Western coast of Kerala in 1870) as well as subsequent professional travels they undertook jointly, Raja Raja Varma organised the various journeys under categories of the many native states they had visited, places of pilgrimage and worship, hill stations and principal cities. ${ }^{77}$ Ravi Varma had lamented his inability to travel abroad for fear of losing his caste, but the long list of sites within India indicated the spatial imagination of the upper caste Malayali gentleman, which now extended beyond its southern province into more unfamiliar spaces. In contemporary Malayalam literature, the trope of the journey was linked to an encounter with hetero-topoi where the self-certainties of the subject were put into question, and the return to the familiarity of the home formed a moment of truth and reconciliation that affirmed selfhood. ${ }^{78}$ If literary experiments employed the journey as a trope for the constitution of the subject, the Varma brothers' approach to travel involved the fashioning of a particular kind of subject, the cultured man. Raja Raja Varma approvingly excerpts Baron Ampthill's address to a student convocation in 1903 exhorting Indian men to travel:

There are two things, which I should like to recommend in particular to the young men of Southern India as means of increasing and spreading culture. The first is Art, and the second is travel, for as regards both of these things it seems to me that you have still much to learn...Suffice it to say that some form of Arts should be the hobby of every cultured man... New scenes engender new ideas, and I strongly advise you to seize any little opportunity you may have to wander to some place where you can rest your minds by contemplating the beauties of nature or the works of man according as your inclinations prompt you. ${ }^{79}$ 
This is an author-produced, peer-reviewed version of this article. The final, definitive version of this document can be found online at Art History, published by Wiley on behalf of the Association of Art Historians. Copyright restrictions may apply. doi: 10.1111/1467-8365.12085

In Raja Raja Varma's writings, travel is imagined as a cultural education not dissimilar to the aristocratic grand tour in Europe and in each case, it remained the preserve of an elite class, not merely because of the costs of travel but also in the particular spatial imagination it engendered. Curiously enough, Raja Raja Varma’s record of places he visited in his diary is followed by a list of 'titled native gentlemen' whom the brothers knew intimately. The spatial imagination is closely bound to class identity and this is perhaps indicated in Ravi Varma's painting. For example, The Student depicts the subaltern standing in the background shadows under the doorway on ambiguous territory, at once a part of the household but not fully a member. Dilip Menon's analysis of the subaltern novel of Malayalam literature asserts that 'homelessness was an existential fact' for the lower castes. Unlike the upper caste novel with its certainties of home and family, the lower caste novel was characterised by a homelessness that not only spoke of their landless state but also their dependence upon their masters. Moreover, the subaltern's territorial imagination did not subscribe to given national borders but according to Menon, inhabited premodern geographies of oceanic travel, renewed by more modern journeys as indentured labour. ${ }^{80}$ In The Student, a servant in the shadows waits upon the reading gentleman, the dim overhead lamp merely marking out his contours, unlike the warm glow of the lamp that suffuses the scholar's face. If the world of books and education afforded the gentleman his freedoms, the subaltern's world was severely circumscribed by his caste restrictions. Kerala's caste hierarchies were amongst the most stringent in the country with certain lower castes like Pulayas and Chermas owned as slaves - even their shadow cast upon a higher caste Brahmin was deemed polluting. Household servants in the Nayar tharavad did not belong to these untouchable castes (who despite the abolition of slavery in 1843, were persecuted) but were often lower caste shudras. Raja Raja Varma notes four servants who travelled with them on their trips - two Brahmins (to cook and maintain the dietary prescriptions based on their caste), one Varar and one shudra. ${ }^{81}$

C. Raja Raja Varma's account of his trip with Prince Marthanda Varma (that was published for private circulation) portrays a geography that is at once imagined as sacred and unchanging as well as transformed by technology. In the tour of North India, holy cities like Banaras and Mathura occupy as central a place on their itinerary as Darjeeling and Agra. Along the journey Raja Raja Varma notes the sacred mythologies that have haunted places, telling stories like the one about the Tinnevelly Brahmin who constructed an irrigation channel to expiate his sins. Soon thereafter, he extols the virtues of the spinning mill whose use of water power indicates a 'triumph of art over nature.' The writing mediates a curious middle ground between an archaic notion of the journey as pilgrimage and the modern tourist's wanderings for site-seeing and pleasure. He prefaces his travelogue with the observation that pilgrimages in the past were fraught with untold dangers of encounters with dacoits and wild beasts, so that those who travelled were never sure of making it back home. In the era of the railway and the telegraph however, not only had time and distance been annihilated, but even pilgrims to the Ganges had increased because of a general feeling of security. ${ }^{82}$ The sacred geography is in fact animated by technological intervention.

After five months on tour in North India, Raja Raja Varma's sense of relief in reaching home is palpable. Sitting in a Malayali house amidst a grove of coconut palms in Ponani, he finds occasion to muse upon his travels where he had seen 'splendid cities, impregnable fortresses, marble palaces, and golden temples, and yet, nowhere had we seen, except on the Himalayas, such a magnificent natural scenery as in this most favoured of lands.' In a prescient story that anticipates Kerala's popular contemporary tourist slogan as 'God's own country', he reports a conversation with A. Seshia Sastri (a Tamil Brahmin who had served as the Dewan of Travancore) who had observed that 'God, after he had created the Universe, formed a land for his own residence - a land which was the miniature of the whole world, a beautiful land of happiness and plenty. That land, was Malabar... ${ }^{83}$

Both the diary and the travel narrative are exemplary genres for the musings of the private interiorised self and its encounters with the world and yet, what is remarkable about Raja Raja Varma's writings is the very absence of any self expression that might indicate his psychological or emotional life. There is the description of the places visited, a record of the events of the day and the occasional flight of Romantic poetry at the sight of a particularly beautiful natural scene, but little indication at all about his inner motivations or desires. In the later years, when he was often struck by migraine like headaches that rendered him incapacitated during his travels, we are treated with a matter-offact description of his symptoms with an oblique reference to Ravi Varma instead 'My brother feels rather lonely without me in his evening drives. ${ }^{, 84}$ Udaya Kumar has noticed a similar disavowal of the private in Malayalam autobiographies of the period and proposed that as a public exhibition of the self, the autobiography is but one mode of intervening in a diverse field of public utterances and rather than seeking for an authentic expressiveness, it is more instructive to view the genre as a performance of selfhood. ${ }^{85}$ 
This is an author-produced, peer-reviewed version of this article. The final, definitive version of this document can be found online at Art History, published by Wiley on behalf of the Association of Art Historians. Copyright restrictions may apply. doi: 10.1111/1467-8365.12085

\section{Conclusion}

For Ravi Varma, perhaps it is only in the affective domestic spaces of these two small paintings where such interiority is given expression. The two paintings are the only works that locate the man within the contemporary world and this allows him to propose questions of selfhood in a manner quite distinct from the identities posed in his mythological paintings or portrait practice. In conjunction with the contemporary Malayalam novel of the day, the paintings participate in fashioning a modern self, where individuality is articulated within a personalised space that had little historical precedence. Despite the predominance of the public sphere as a place for the contestation and negotiation of identities, the refashioning of the domestic space played an equally important role in the formation of masculine identity. To associate the domestic with the feminine alone would undermine the significance of the interior in the constitution of modern subjectivity.

Contemporary literary and historical studies have viewed the rise of the Malayalam novel as inextricably linked to the crisis of the self that followed the dissolution of the tharavad centred life, but it has been much harder to view the tensions and dissatisfactions with the past in the visual archive, where Ravi Varma presents a harmonious vision of the past and even contemporary subjects tend to be romanticised. G. Arunima even suggests that Ravi Varma's painting was at odds with the novel in that it failed to produce any images of city life and its promises of anonymity that had so enamoured the novel, despite Ravi Varma having spent much time in Bombay. ${ }^{86}$ Despite the absence of city imagery, Ravi Varma's paintings of men reading are strongly invested in an exploration of spaces, both real and imagined, familiar and unknown, representational and lived, as an important aspect of the modern experience. His investment in the interior was emblematic of the inward turn that characterized modern life but it also calls for a revision of the traditional role of the man within domestic spaces. By inscribing the man within the deepest recesses of the tharavad, Ravi Varma re-envisioned the modern interior as a space for the cultivation of the self.

\section{Notes}

I would like to thank the two anonymous reviewers for their helpful comments on the article, Mr $\mathrm{R}$. Nandakumar for numerous discussions on Ravi Varma and J. Devika for her remarks on an earlier draft.

\footnotetext{
${ }^{1}$ C. Raja Raja Varma’s diaries have been published as Raja Ravi Varma: Portrait of an Artist The Diary of C. Raja Raja Varma ed. Erwin Neumayer and Christine Schelberger, New Delhi, 2005.

${ }^{2}$ Sir George Christopher Molesworth Birdwood, Paris Universal Exhibition of 1878: Handbook to the British Indian Section, London, 1878, 76.

${ }^{3}$ Partha Chatterjee, The Nation and its Fragments: Colonial and Postcolonial Histories Princeton, 1994, 3-13.

${ }^{4}$ For an analysis of vernacular print culture see, G. Arunima, 'Imagining communities - differently: Print, language and the (public sphere) in colonial Kerala,’ Indian Economic and Social History Review Vol. 43 No.1,

2006 p. 63-76 and Francesca Orsini for an example of the Hindi public sphere. Francesca Orsini, The Hindi Public Sphere (1920-1940): Language and Literature in the age of Nationalism, New York, 2002. Mary Beth Heston has proposed a mixed public sphere in Kerala based on an architectural aesthetic that reflected the tastes of both the native elite as well as Europeans. Mary Beth Heston, 'Mixed messages in a new 'public’ Travancore: Building the capital 1860 -1880,' Art History Vol. 31, No. 2, 2008, 211-247.

${ }^{5}$ See Robin D. Jones, Interiors of Empire, Manchester, 2007, 129-133 and Dipesh Chakraborty, “The difference-deferral of (a) colonial modernity: Public debates on domesticity in British Bengal, History Workshop, 36, 1993, 1-34.

${ }^{6}$ J. Devika, ‘Negotiating women’s social space: Public debates on gender in early modern Kerala, India’ Inter Asia Cultural Studies, 7:1, 2003, 43-61.

${ }^{7}$ See Dilip Menon, 'No, Not the Nation: Lower Caste Malayalam Novels of the Nineteenth Century’ in Meenakshi Mukherjee, ed., Early Novels in India Delhi, 2002, 41-72.

${ }^{8}$ For an analysis of how Kangra painting employs narrative and visual strategies in engaging the sakhi (female companion) to connect the inner world of the nayika with the outside world of her lover, see Molly Emma Aitken, "Spectatorship and femininity in Kangra style painting," in Vidya Dehejia, ed., Representing the body: Gender issues in Indian art (New Delhi: Kali for Women, 1997), pp.83-101.

${ }^{9}$ Gas lamps were also in use, imported from Germany at the time, as indicated by Raja Raja Varma in his diary.

${ }^{10}$ G. Arunima, There Comes Papa: Colonialism and the Transformation of Matriliny in Kerala, Malabar c. $1850-1940$, Hyderabad, 2003.

11 J. Devika, 'Negotiating women’s social space' 47-48. A more detailed enunciation of her argument is found in J. Devika, Engendering Individuals: The Language of Re-forming in Early Twentieth Century Keralam, Hyderabad, 2007.
} 
This is an author-produced, peer-reviewed version of this article. The final, definitive version of this document can be found online at Art History, published by Wiley on behalf of the Association of Art Historians. Copyright restrictions may apply. doi: 10.1111/1467-8365.12085

12 Dilip Menon addresses the role of travel in Saraswativijayam in the Afterword to his translation of the book. Potheri Kunhambu, Saraswativijayam trans. Dilip Menon, New Delhi, 2008, 106-113. Udaya Kumar references the trope of the journey in Indulekha in 'Seeing and reading: The early Malayalam novel and some questions of visibility’, Meenakshi Mukherjee, ed., Early Novels in India, Delhi, 2002, 161-192.

${ }^{13}$ Walter Benjamin, Arcades Project, Cambridge: Harvard University Press, 1999, 220.

${ }^{14}$ See for instance, Susan Sidlauskus, Body, Place, and Self in Nineteenth-Century Painting Cambridge, 2000; Sharon Marcus, Apartment Stories, Berkeley, 1999; Charles Rice, Emergence of the Interior: Architecture, $\quad$ Modernity, Domesticity London, 2007; The Darker Side of Light: The Arts of Privacy, 1850-1900, ed. Peter Parshall, Washington D.C, 2009.

${ }^{15}$ Penny Sparke, The Modern Interior, London, 2008, 13.

${ }^{16}$ Walter Benjamin, Arcades Project, Cambridge: Harvard University Press, 1999, 216.

${ }^{17}$ Frances Guerin, A Culture of Light, Minneapolis, 2005.

${ }^{18}$ See for instance Martin Jay’s characterization of Cartesian perspectivalism to the modern Western epoch. 'Scopic Regimes of Modernity' in Hal Foster ed., Vision and Visuality, Seattle, 3-23.

${ }^{19}$ Christian missionaries frequently drew upon metaphors of light to describe their role in India. See for example, Thomas Whitehouse, Lingerings of Light in a Dark Land: Researches into the Syrian Church of Malabar, London, 1873.

${ }^{20}$ G. Arunima, 'Writing culture: Of modernity and the Malayalam novel,’ Studies in History, Vol. 13, No.1, Jan- Jun 1997, $271-290$.

${ }^{21}$ This is a conjecture based on the popularity of the novels and his interest in reading subjects as there is very little mention of Malayalam literature in Raja Raja Varma’s diaries although he routinely chronicles his library visits and his English reading materials.

${ }^{22}$ Michael Fried, Absorption and Theatricality: Painting and Beholder in the Age of Diderot, Berkeley, 1980.

${ }^{23}$ Christopher Pinney has made this claim about Ravi Varma and proposed that it endeared him to his imperial patrons. However, much of Ravi Varma's oeuvre also subscribes to the opposing 'theatrical' ideal that Pinney finds common with practices of darshan in Indian popular culture. Photos of the Gods, New Delhi, 2004, 22-23.

${ }^{24}$ Henri Lefebvre, The Production of Space, trans. Donald Nicholson-Smith, Boston, 1991.

${ }^{25}$ See for instance the construction of the modern self in Udaya Kumar, 'Self, Body and Inner Sense: Some Reflections on Sree Narayan Guru and Kumaran Asan,' Studies in History, Vol. 13 (2), 1997, 247-70 and Dilip Menon, 'No, Not the Nation: Lower Caste Malayalam Novels of the Nineteenth Century’, Meenakshi Mukherjee, ed., Early Novels in India (Delhi: Sahitya Akademi, 2002) p. 41-72.

${ }^{26}$ Sudipta Kaviraj, ‘The invention of private life', Telling Lives in India: Biography, Autobiography and Life History” ed. David Arnold and Stuart Blackburn, Bloomington and Indianapolis, 2004, 83-115.

${ }^{27}$ Benedict Anderson, Imagined Communities, London, 1983.

${ }^{28}$ Partha Mitter, 'Mechanical reproduction and the world of the colonial artist' in Beyond Appearances: Visual Practices and Ideologies in Modern India, ed. Sumathy Ramaswamy, New Delhi, 2003, 1-30

${ }^{29}$ Rupika Chawla, Raja Ravi Varma: Painter of Colonial India, Ahmedabad, 2010, 40.

${ }^{30}$ After the reference to the death of Kochu Koil Thampuran in Raja Raja Varma's diary there is in fact, no entry for the 14 days between $30^{\text {th }}$ March, $1903-12^{\text {th }}$ April, 1903. One might surmise that the lapse concurred with an abbreviated mourning ritual of 14 days instead of the customary year. Erwin Neumayer and Christine Schelberger, Raja Ravi Varma, 158.

${ }^{31}$ This is complicated by the fact that the scholar in the first portrait has been identified as C. Raja Raja Varma by Neumayer and Schelberger. Although I have not been able to find corroborating evidence for the claim, the portrayal of each other as scholars rather than painters is an interesting choice.

${ }^{32}$ See Francesca Orsini, Print and Pleasure: Popular Literature and Entertaining Fictions in Colonial North India (Ranikhet: Permanent Black, 2009) and Bhavani Raman, Document Raj: Writing and Scribes in Early Colonial South India (Chicago and London: University of Chicago Press, 2012).

${ }^{33}$ I am grateful to Nandakumar Raman for bringing this to my attention.

${ }^{34}$ For an interesting account of the ambiguous place of western furniture in Bengali homes and novels see Supriya Chaudhury, 'Phantasmagorias of the interior: Furniture, modernity and early Bengali fiction', Journal of Victorian Culture, vol. 15, no. 2, 2010, 173-193.

35 This was part of a speech delivered by Lord Curzon at the inauguration of an Indian art exhibition that accompanied the Delhi Durbar in 1902. Lord Curzon in India: being a selection from his speeches as viceroy and governor general of India, London, $1906,207$.

${ }^{36}$ The remark was included in a paper presented at a workshop on Cultures and Empires, Stanford University, February, 1999. G. Arunima, 'Fantasies, phantoms and funny jokes: The 'city' and colonial modernity.'

${ }^{37}$ Udaya Kumar, 'Seeing and reading,' 165.

${ }^{38}$ O.C. Menon, Indulekha, trans. Anitha Devasia, New Delhi, 2006, 167-8.

${ }^{39}$ Robin D. Jones, Interiors of Empire, 129-133.

${ }^{40}$ Report on the Census of Travancore, Trivandrum: Travancore, 1876, 124.

${ }^{41}$ C.V. Raman Pillai, Marthanda Varma trans. B.K. Menon, New Delhi, 1998, 42. 
This is an author-produced, peer-reviewed version of this article. The final, definitive version of this document can be found online at Art History, published by Wiley on behalf of the Association of Art Historians. Copyright restrictions may apply. doi: 10.1111/1467-8365.12085

${ }^{42}$ See contemporary artists N. Pushpamala and Clare Arni's series Native Women Of South India - Manners And Customs, 2000-2004. They single out two works by Raja Ravi Varma and one by his brother, Raja Raja Varma: 'Lady in Moonlight,' 'Lakshmi’ and 'Returning from the Tank.'

${ }^{43}$ V.S. Pramar, A Social History of Indian Architecture New Delhi, 2005, 48.

${ }^{44}$ Samuel Mateer, The Land of Charity: A Descriptive account of Travancore and its People, London, 1871, 54.

${ }^{45}$ For the impact of matriliny on architecture, see Balakrishnan Menon Parameswaran, Matriliny and Domestic Morphology: A Study of the Nair Tarawads of Malabar M.A Thesis, McGill University, 1998

${ }^{46}$ C.V. Raman Pillai, Marthanda Varma, 42.

${ }^{47}$ Erwin Neumayer and Christine Schelberger, Raja Ravi Varma: Portrait of an Artist The Diary of C. Raja Raja Varma, 184.

${ }^{48}$ Mary Beth Heston, 'Mixed messages in a new 'public' Travancore, 211-247.

${ }^{49}$ The notion of a 'Malayali' identity commonly appears in the writings of the period including Raja Raja Varma and Potheri Kunhambu. In Kunhambu's novel, it does not displace caste categories, but nevertheless envisions a broad based cultural identity premised upon territorial and linguistic grounds.

${ }^{50}$ C. Raja Raja Varma, A narrative of the tour in upper India of His Highness Prince Martanda Varma, of Travancore, Trivandrum, 1896, 99. Ravi Varma had in fact started construction on a new building that blended westernised elements beside his studio at Killimanoor, but died while the construction was still in its early stages.

${ }^{51}$ Both Geeta Kapur and R. Nandakumar make this point in their respective essays. Geeta Kapur, 'Ravi Varma: Representational dilemmas of a nineteenth century Indian painter,' Journal of Arts and Ideas No. 17-18, 1989, 59-80 and R. Nandakumar 'Raja Ravi Varma in the realm of the public,' Journal of Arts and Ideas No. 27-28, 1995, 41-56.

${ }^{52}$ Potheri Kunhambu notes the Malayali dislike for the moustache in Saraswativijayam, 31.

${ }^{53}$ C. Raja Raja Varma, A narrative of the tour, 80.

${ }^{54}$ J. Forbes Watson, The Textile Manufactures and the Costumes of the People of India, London, 1866, 54.

${ }^{55}$ A US trade report from 1915 notes that Indians were most particular about stylistic details like the depth and shape of the cuff or the length of the sleeve and preferred to have native tailors stitch their clothes for them rather than buy them. Henry D. Baker, British India with Notes on Ceylon, Afghanistan and Tibet, Special Consular Reports, Vol. 72, Washington, 1915, 261.

${ }^{56}$ See Emma Tarlo, Clothing Matters, (Chicago: University of Chicago Press, 1996), 48.

${ }^{57}$ Emma Tarlo, Clothing Matters, 50.

${ }^{58}$ Kathleen Gough, quoted in G. Arunima, There Comes Papa, 5.

${ }^{59}$ An indication of this is seen in Indulekha where a Nambudri suitor is proposed for Indulekha despite his obvious uncouth character or a consideration of Indulekha's own desires.

${ }^{60}$ See G. Arunima, There Comes Papa, 22.

${ }^{61}$ Both G. Arunima and R. Nandakumar have read Ravi Varma's There Comes Papa as emblematic of the new ideals for nuclear families that accompanied the dissolution of the tharawad. R. Nandakumar 'The missing male: The female figures of Ravi Varma and the concepts of family, marriage and fatherhood in nineteenth century Kerala,' South Indian Studies, January-June 1996, 54-82 and G. Arunima, There Comes Papa, 2003.

${ }^{62}$ Douglas Haynes has noted the predominance of the nuclear family ideal in advertising imagery of insurance between 1918-1940, to the extent that no examples exist of the extended joint family, which was undoubtedly the prevailing norm. 'Masculinity, advertising and the reproduction of the middle-class family in Western India, 1918-1940', Being Middle Class in India ed. Henrike Donner, New York, 2011, 23-46.

${ }^{63}$ Nandakumar, ‘The missing male,' 77.

${ }^{64}$ Gaston Bachelard, The Poetics of Space, Boston, 1994, 12.

${ }^{65}$ Henri Lefebvre, The Production of Space, trans. David Nicholson Smith, Oxford, 1991, 309.

${ }^{66}$ Dipesh Chakraborty, Provincializing Europe, Princeton: Princeton, 2000, 180-213.

${ }^{67}$ Swati Chattopadhyay argues for a more violent displacement of women from Calcutta's public spaces, proposing that the nostalgic recalling of adda in contemporary studies is in fact evidence of a continued system of male privilege. Swati Chattopadhyay, Representing Calcutta: Modernity, Nationalism and the Colonial Uncanny, New York, 2006,185.

${ }^{68}$ G. Arunima, There Comes Papa, 128.

${ }^{69}$ The novel in fact, begins with the protagonist Madhavan fuming at the karanavan for refusing to provide for the English education of a younger cousin, Shinnan.

${ }^{70}$ E.M.J. Veniyoor, Raja Ravi Varma, Trivandrum, 1981, 52.

${ }^{71}$ Quoted in J. Devika, Engendering Individuals, 50.

${ }^{72}$ Hollis Clayson, “Looking within the cell of privacy”, The Darker Side of Light: The Arts of Privacy, 1850- 1900, ed. Peter Parshall, Washington D.C, 2009, 56.

${ }^{73}$ Veniyoor quotes from the Malayalam biography by N. Balakrishnan Nair, Raja Ravi Varma, 27. 
This is an author-produced, peer-reviewed version of this article. The final, definitive version of this document can be found online at Art History, published by Wiley on behalf of the Association of Art Historians. Copyright restrictions may apply. doi: 10.1111/1467-8365.12085

${ }^{74}$ Christopher Reed, Not at Home: The Suppression of Domesticity in Modern Art and Architecture, London, 1996.

${ }^{75}$ Charles Rice, The Emergence of the Interior: Architecture, Modernity, Domesticity, New York and London, 2007.

${ }^{76}$ The journals that comprised his collection included The Artist (London), Royal Academy Pictures (London), Moderne Kunst (Berlin), and The Portfolio (London) amongst others.

${ }^{77}$ Erwin Neumayer and Christine Schelberger ed., Raja Ravi Varma, 78.

${ }^{78}$ Udaya Kumar 'Seeing and Reading' 173-4. Also see, Dilip Menon, 'A place elsewhere: The nineteenth century subaltern novel in Malayalam,' The Blindness of Insight: Essays on Caste in Modern India, New Delhi, 2011, 73-109.

${ }^{79}$ Erwin Neumayer and Christine Schelberger ed., Raja Ravi Varma, 146. The entire speech is reprinted in Baron Ampthill, 'An address delivered to the graduates admitted at the convocation of the senate of the University of Madras,' Madras, 1903. Mss/Eur/233/59.

${ }^{80}$ Dilip Menon, ‘A Place Elsewhere,’ 73-109.

${ }^{81}$ He refers to two of them by name - Venku, the Brahmin who was associated with the royal family of Travancore and Ayyapan, the shudra who was a trusted man and had been in their service for many years, Erwin Neumayer and Christine Schelberger ed., Raja Ravi Varma, 98 and 130. Despite their anxieties to maintain caste rituals even while travelling, there is reason to believe that the Varma brothers were somewhat sympathetic to the efforts of lower caste Christian converts who had embraced an English education. Both the brothers contributed to the Indian Ladies Magazine, a women's magazine edited by Kamala Sathianandan, who belonged to a well- known Tamil literary family that had converted to Christianity as a way to escape caste restrictions.

${ }^{82}$ C. Raja Raja Varma, A narrative of the tour, 2-3.

${ }^{83}$ C. Raja Raja Varma, A narrative of the tour, 98-99.

${ }^{84}$ Erwin Neumayer and Christine Schelberger ed., Raja Ravi Varma, 186.

${ }^{85}$ Udaya Kumar 'Autobiography as a way of writing history,' History in the Vernacular ed. Raizuddin Aquil and Partha Chatterjee, Ranikhet, 2008, 418-448.

${ }^{86}$ G. Arunima, 'Face value: Ravi Varma's portraiture and the project of colonial modernity’ Indian Economic Social History Review Vol. 40 , No. 1 , 2003, 75-76. 